\title{
Selecting Reading Materials
}

Wisely

Ivannia Jiménez Arias ${ }^{1}$

Universidad Nacional, Costa Rica

\section{RESUMEN}

Se analizan criterios por tenerse en cuenta en la selección de materiales para el desarrollo de la comprensión de lectura en una segunda lengua. Se propone una altemativa para elegir textos. La exploración de estos aspectos resulta muy útil en los cursos de comprensión de lectura al tenerse al estudiante como punto de partida.

\section{Abstract}

An analysis is carried out on criteria for selecting materials for the development of reading comprehension in a second language. A proposal for selecting reading texts is described. This approach is very useful in reading comprehension courses because it is student-centered.

Palabras claves: aprendizaje de segundas lenguas, comprensión de lectura, recursos pedagógicos

Keywords: second-language learning, reading comprehension, teaching resources

Because selecting reading materials is just one of teachers' many daily duties, most teachers do this task based on their own criteria with no further considerations. They hardly ever involve the

Correo electrónico: Ivanniaja@costarricense.cr. 
students in this reading selection process, even though they are meant to be the final recipients of the reading materials. As a consequence, the reading materials chosen by the instructors are of ten inappropriate. According to Richard R. Day, "One of the more complex tasks facing the English as a foreign language (EFL) reading teacher is the selection of appropriate reading passages." 2

Selecting reading materials for any particular ESL/EFL class must be a thoughtful process rather than a random one. The students must be actively involved in this process if teachers want to adopt appropriate reading materials for the class. Due to the relevance of the process of selecting reading passages, researchers have devoted much time to analyzing the different aspects involved in the selection process. Field researchers, such as Melvin \& Stout, Fox, and Gebhard, have identified certain factors that need to be considered when preparing material for ESL-EFL classes. ${ }^{3}$

The teachers who decide to select reading materials wisely need to devote some of their valuable time to analyzing each one of these aspects. If teachers successfully select a variety of appropriate texts, the students will perceive reading as an interesting and valuable activity. On the contrary, "if the passage chosen is inappropriate for whatever reason, the chances of success for that particular lesson are substantially lessened." 4 The most significant factors in the reading selection process are related to the students: the students' level, interests, needs, and background knowledge. Other factors are related to the text itself: content, relevance and authenticity.

The approach presented here represents an attempt to provide teachers with a practical alternative for selecting reading materials

\footnotetext{
Richard Day, "Selecting a Passage for the EFL Reading Class," Forum 32 (1994): 20.

3 Bernice Melvin \& David Stout, "Motivating Language Learners through Authentic Materials," Interactive Language Teaching, ed. Wilga Rivers (New York: Cambridge University Press, 1987) 44-56; G. Fox, "Text Selection and the Role It Plays in Motivation," The Language Teacher, 10 (1989): 8-10: Jerry Gebhard, "Relevancy, Authenticity, Comprehensibility and Selection of EFL Materials," PASAA. 19 (1989): 87-90.

+ Day. 20.
} 
wisely and efficiently. The analysis of these aspects should not bear any further complication for the teacher, yet it offers great benefits. Students are actively involved in this process and they should be motivated to provide their own reading materials for the class. A sample application will be discussed to illustrate how to apply the approach that is presented in this article. The aspects discussed here are not exhaustive; on the contrary, they provide a basis to which classroom teachers can add, depending on their own teaching situations.

\section{Factors directly related to the students}

\section{Students' Level}

The instructor needs to be aware of the students' level and acknowledge that fact when selecting the materials for the reading class. Researchers such as Melvin \& Stout, Lotherington, and Fox suggest that the educator needs to know which materials are suitable for the students' level. Gebhard asserts that the material that is selected for the ESL/EFL class should not go beyond the students' level. Similarly, Melvin \& Stout state that "the level of the students will influence the selection of material". 5

Asking the students to read material that goes beyond their level might be counterproductive since learners may feel that they are simply incapable of reading in the target language. Some researchers have suggested that one alternative for providing the students with appropriate reading materials is simplifying the texts in order to make them accessible for the students. However, this idea has received little support from field researchers and professionals.

It is better to simplify the reading process rather than the text. Instructors can provide the students with a variety of reading techniques in order to facilitate the reading comprehension process. Instructors should start using less complicated texts, selections from

$5 \quad$ Melvin \& Stout, 50. 
local newspapers such as The Tico Times (always avoiding texts oriented toward tourists with whom students do not identify) and popular magazines such as Better Homes and Gardens. Later they can use more complex texts as the students increase their reading fluency, as well as texts with different degrees of difficulty. Once the instructor has determined the students' level, she can choose appropriate sources to select reading materials for each particular group of students. Those teachers who are willing to select reading materials wisely can never neglect students' interests.

\section{Students'Interests}

Researchers have come to the agreement that materials selected for the ESL/EFL reading class ought to satisfy students' interests. ${ }^{6}$ Lotherington states that no matter how difficult or easy a text might be, it would be boring or difficult to read if it is not interesting to the learner. ${ }^{7}$ Similarly, Fox states that the first step for material selection is "to find material that the students are likely to be interested in." Gebhard and Papalia affirm that the material for the ESL/EFL class should be selected on the basis of students' interests.

With the purpose of finding out students' interests the instructor should make an assessment about the students' interests and needs at the beginning of the period. Through a survey, interviews or just an informal discussion, the instructor can ask the students to suggest appropriate topics for the class. See Appendix 1 for an example of a survey applied for this purpose. They should also be encouraged to bring their own contributions to the class. Educators can make the

\footnotetext{
- Francoise Grellet, Developing Reading Skills: A Practical Guide to Reading Comprehension Exercises (New York: Cambridge: Cambridge University Press, 1981); Anthony Papalia, "Interaction of Reader and Text," Interactive Language Teaching, ed. W. Rivers (New York: Cambridge University Press, 1987) 70-83: Ellen Cray, "Why Teachers Should Develop Their Own Materials," TESL Talk, 18 (1988): 82-88.

7 Heather Lotherington-Woloszyn, "On Simplified and Simplifying Materials for ESL Reading," TESL Talk, 18 (1988): 112- 121.

* Fox, 10.
} 
students responsible for selecting relevant reading materials in order to create a file of readings available for all the students in the class.

Interest is closely related to motivation, as Richard Day proposes: "when the topic of a passage is not of interest to students, their motivation to read is substantially lessened. Without this motivation, it is exceedingly difficult to meet one of the generally accepted aims of a reading program: to help get the learners to read in English on their own, outside the reading classroom." Considering the students' interests in the reading selection process is as important as exploring the students' needs.

\section{Students' Needs}

There has been a great deal of agreement among researcher about the importance of considering students' needs in the material selection process for the ESL-EFL reading class. Gebhard states that the teachers should always discover the students' needs before making any decisions about the course content. Similarly, Gray says that the teacher should be aware of the students' needs to be able to help them fulfill these needs by providing appropriate materials. According to Grellet, there are certain needs that all the students have in addition to their individual needs. For instance, all students need to be able to read fast, to time themselves, to know basic reading techniques, and others. Educators must then take into account common needs as well as the individual needs in the process of material selection. The mismatch between students' expectations in regards to their needs and interests can result in students' frustration, which might imply failure on a reading course.

\section{Students' Background Knowledge}

Another significant criterion for selecting appropriate material for the EFL reading class is students' background knowledge. In order

\footnotetext{
Day, 2.
} 
to provide the students with suitable material, the instructor must be familiar with the students' background knowledge. Research findings have emphasized the importance of considering this aspect in the material selection process. Smith, for example, affirms that reading cannot be separated from the readers' previous knowledge. ${ }^{10}$ Referring to ESL readers in particular, Lotherington-Woloszyn and Nunan agree that the lack of background knowledge may cause more difficulties for the ESL reader than language complexity does. ${ }^{11}$ Likewise, Fox asserts that "background knowledge is an important part of the students' ability to read and understand a particular text."12

- It is possible and not uncommon for a reader to understand every word in a passage, without really understanding what the words mean. For this reason, the role of the teacher is to consider students' background knowledge when selecting materials for the reading class. This does not imply that it is not possible to use texts for which the students or the instructor himself lack the background knowledge, but rather that it is the teacher's responsibility to provide the students with the information required for comprehending a particular text. Pre-reading activities are particularly useful for this purpose.

In other words, the teacher must be aware of the need to facilitate the reading comprehension process by either giving the students the background knowledge along with the reading material, or requiring them to acquire it by their own means, for example, doing some kind of informal research.

To sum up, the issue of students' background knowledge should be considered in the text selection process and course design due to the fact that background knowledge plays a critical role in the reading comprehension process. This aspect is particularly important when the

\footnotetext{
10) Frank Smith, Understanding Reading: A Psycholinguistic Analysis of Reading and Learning to Read, $4^{\text {th }}$ ed. (Hillsdale, New Jersey: Erlbaum, 1988) 179.

11 Lotherington-Woloszyn; David Nunan, Designing Tasks for the Communicative Classroom (New York: Cambridge University Press, 1989).

Fox. 10
} 
students need to read in a second or foreign language, for they possible lack the necessary understanding of the target culture.

\section{Aspects related to the text}

\section{Relevance}

Choosing reading materials wisely also implies considering the text itself. The topic, the type of text and the information it sustains make the text relevant. Students must find that the reading material used in the course is relevant for their professional lives. Richards mentions that the readings should be related to real world reading purposes. For this reason, it is necessary to involve the learners to contribute to the reading selection process. Permitting the students to contributing will certainly benefit the educator as well.

Gebhard asserts that «understanding the needs of students in specific fields can provide the means through which materials can be selected and created.» ${ }^{13}$ The teachers can determine how appropriate the reading materials are by considering whether they are relevant to the learner or not (Lotherington).

If the instructor carefully selects pertinent reading material for the EFL class, the students are more likely to be interested in the class and will probably be anxious to use diverse strategies to comprehend the material. The following sample is an extract from a three-page text which has been used in a Technical English course for students of Veterinary Medicine.

\section{Gum Diseases}

According to the American Veterinary Dental Society, more than 80 percent of dogs and 70 percent of cats develop gum disease by the age of three years. Periodontal disease is the most common dental

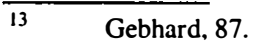


condition affecting dogs and cats. Infection and inflammation of the gums and supporting tissues of the teeth are caused by bacteria present in plaque and calculus (tartar). The problem begins when plaque and calculus are allowed to build up on a pet's teeth, especially below the gumline. Bad breath, bleeding and inflammation of the gums, receding gums, loosening and the eventual loss of teeth are characteristic of the condition. Prophylactic treatment to keep the teeth clean is therefore of great importance. ${ }^{14}$

This text was relevant for the students because they showed a great interest in the topic and the text itself. As a result, the students could read the text without any difficulty, even though this is their first year in college. In order to evaluate the importance of relevance, the same text was used in a reading course for students from a variety of majors. Even though I used pertinent activities to introduce the topic and activate students' background knowledge related to their previous experiences with pets, the students insisted that the text was not at all interesting and that it was very difficult to understand. Some of them even said that they could understand many words but they were not able to grasp the ideas. To illustrate, they could recognize words such as "stomatitis" and "periodontal" but they did not know what they mean.

\section{Content}

Fox and others agree that the most important criterion for selecting reading material for the ESL class is content. They affirm that if the selected content is interesting for the students, they will be successful in the reading process no matter how difficult the text might be. When the students are required to read a complex text that is at

\footnotetext{
$14 \quad$ Frank J. M. Verstraete, "Veterinary Dentistry: Dental Care for Pets," (Feb. 23, 2004) accessed November 2005, <http:www.netpets.org/contact.html>.
} 
the same time interesting for them or that refers to knowledge required in other classes, they will probably make more effort to comprehend it, and they will probably use a variety of strategies to digest it.

In order to select reading material with appropriate contents, it is necessary to take the students' interests and needs into account. This can be done by asking the students to make a list of topics that they will study in their specific fields or that they would like to read for fun. A good selection of readings can result from asking the students to bring their own material to the class. Students could then devote some class time to studying this material. Teachers might want to get copies of the readings and classify them according to field of study for future reference.

To illustrate, the following passage was taken from a text chosen for International Affairs students who are very concerned about human rights.

EDITORIAL: AMERICA'S SHAME / THIS NATION NO LONGER SHINES ON HUMAN RIGHTS

Sunday, May 28, 2006

Pittsburgh Post-Gazette

The United States being hauled up before the U.N. Committee Against Torture in Geneva earlier this month was a sharp reminder of how America's reputation as a beacon of human rights has sagged in recent years.

There was a time when the United States could go on the offensive in international forums against countries that were human rights violators. It could do that since its position was solidly based on a strong record of respect of civil rights and deeply entrenched rule of law at home.

That base now no longer exists, and American professions of indignation at other countries' violations of human rights have a tinny ring in the light of what has happened to the United States in that 
regard. It isn't so much that the United States has taken strong measures at home and abroad in response to the $9 / 11$ attacks and to seek to preclude other such events. That was normal. It is rather the degree to which the United States has violated its own previous standards of justice, in the name of $9 / 11$, in the name of what is sold to the American public as defense of U.S. national security. ${ }^{15}$

Not only did the students enjoy reading the text, but they read and analyzed it with no difficulty. The topic of human rights and torture was discussed in class with the participation of most of the students. They referred to the violation of human rights in Costa Rica and other nations as well.

\section{Authenticity}

Some researchers regard authenticity as another important criterion for the selection of readings for the ESL/EFL class. ${ }^{16}$ However, whether the material used for ESL/EFL classes should be authentic or not has been widely questioned by those who advocate the use of teacher-made materials. Among those who advocate the use of authentic material, Melvin \& Stout state that teachers should take full advantage of the potential benefits of authentic materials. ${ }^{17}$ In a like manner, Gebhard points out that authenticity should be part of the criteria taken into account when selecting appropriate reading material for ESL classes.

The rationale for selecting authentic material may include the following:

- $\quad$ Students need to be able to comprehend real-life language.

\footnotetext{
is Editorial: America's shame/This nation no longer shines on human rights. (May 28, 2006) accessed June 2006 <http://www.post-gazette.com/pg/06148/693574-192.stm>.

16. Melvin: Gebhard: Cray and Rivers.

17 Melvin \& Stout, 44.
} 
- Teachers can take advantage of the grammatical aspects found in the texts.

- $\quad$ Students will be prepared to read any type of text.

- The fact that language is simplified does not ensure comprehension.

- We can provide the students with different strategies to ensure a better comprehension.

- It is better to simplify the reading process, rather than the text. ${ }^{18}$

On the other hand, there are researchers and practitioners who consider that teachers should create their own reading materials or adapt existing ones. Researchers such as Lotherington-Woloszcyn and Cray ${ }^{19}$ justify the adaptation of reading materials in order to satisfy students' needs.

The reasons that they have provided for the use of simplified texts are as follows:

- $\quad$ Adapting materials can make them accessible, interesting and informative.

- $\quad$ Arranging materials around one theme allows the learner to build up background knowledge of the content.

- Attention should be given to what the learners find easy and interesting.

- If the text is poorly presented, it can always be improved.

- $\quad$ Teacher-created materials are based on authentic texts.

- They allow teachers to evaluate their students.

Teachers must be open minded and carefully analyze the advantages and disadvantages of using both commercial and teachermade materials; in this way they can make informed decisions with

\footnotetext{
$18 \quad$ Gebhard.

19 See Lotherington-Woloszyn; Cray provides additional reasons.
} 
the purpose of helping the students benefit the most from the teachinglearning process.

\section{Sample Application}

To illustrate the above considerations, a text was chosen from The Tico Times (see Appendix 2) as a result of a thoughtful reading selection process. This text was selected based on the following analysis:

1. Students' level. The students' level required for this text is low intermediate. The students must know certain grammatical structures which might interfere with the comprehension process; for example, there $+b e$, modal auxiliaries, noun phrases, the different meaning forms of the -ing ending. If the students do not know these basic structures, reading the material might make the students feel that they are unable to read in English.

2. Students' interests. Interest in the topic(s) might make the reading process pleasant no matter how difficult the passage is. The text was selected after having surveyed the students on their particular interests and having determined that the group was interested in the topic of history, particularly Costa Rican history.

3. Students' needs. Since students' needs are one of the most important aspects to consider when selecting reading materials for the ESL-EFL class, the fact that the students' field of studyHistory-was taken into account for choosing this text. In addition, the students had stated their need to do research on Costa Rican history.

4. Students' background knowledge Providing suitable material for the reading class implies taking the students' background knowledge into account. The target students in this case probably know a lot about history and Costa Rican, but they probably do 
not know the origin of Costa Rican street names, since this is not an issue commonly covered in history books. The students' background knowledge eased the comprehension of the text.

5. Relevance. The selected material is related to the student's real world reading purposes, the students can see that it is relevant for their careers. The purpose is to lead the students to understand that the reading process will contribute to their knowledge, and that they can actually learn something new from the texts.

6. Authenticity. The new technologies have opened a whole new world of possibilities for reading materials. Teachers should take full advantage of the potential benefits of authentic materials available. The authenticity of the text was also taken into account for its selection. In addition, it is important to motivate the students to avoid reading texts which are automatically translated in the net because of the erroneous translations they might get.

In order to select reading materials wisely for a particular class, the teacher needs to gather information regarding students' fields of study, level, interests, needsand motivation. Based on this information, the instructor can start analyzing a variety of texts in order to select those which seem appropriate for each particular class. For this purpose, the teacher must consider not only the student-related aspects, but also the text itself. Time must be devoted to our students in our daily teaching practice because every one of them has infinite potential instructors must take advantage of that.

\section{Conclusion}

The purpose of selecting reading materials wisely for the ESL/ EFL class implies the teacher awareness as well as student's involvement in the material selection process. EFL/ESL teachers are expected to provide students with appropriate reading materials. For 
this reason, the reading selection process should be a thoughtful process of carefully consideration to those factors involved in this process. In this important process of selecting the material for a reading class, the teacher cannot neglect the students' level, interests, needs and background knowledge in order to consider text difficulty, content and authenticity.

This text selection process requires some effort on the instructor. Some form of assessment is crucial in order to compile an appropriate set of reading materials for the class: a survey, an informal discussion, individual interviews, or any other form of inquiry can give the instructors some insight of what type of materials to select for each particular class.

Selecting appropriate reading materials for the ESL/EFL class is certainly time consuming, but it is really beneficial for the students as well as the teacher. Smith points out that "for beginners and experienced readers alike, there is always the possibility of fluent reading and the possibility of difficult reading." ${ }^{20}$ Consequently, the teacher can enhance the reading process by providing the students with appropriate texts.

Smith, 174. 


\section{Appendix 1}

The following is a brief survey which has been used for the purpose of gathering information on students' reading interests and needs.

\section{UNIVERSIDAD NACIONAL}

FACULTAD DE FILOSOFÍA Y LETRAS

ESCUELA DE LITERATURA Y CIENCIAS DEL LENGUAJE

INGLÉS ESPECIALIZADO (RI, IDELA, IEM, SOCIOLOGÍA E HISTORIA)

\section{ENCUESTA A ESTUDIANTES}

Con el propósito de elaborar material didáctico para el curso de Inglés especializado que se impartirá a partir del próximo año, solicitamos su colaboración para que responda la presente encuesta. La información que nos brinde es estrictamente confidencial y será utilizada únicamente con fines académicos. No es necesario que escriba su nombre. Puede agregar comentarios y observaciones. Agradeceremos su valiosa colaboración.

\section{INSTRUCCIONES GENERALES}

Responda las preguntas y marque con una $\mathbf{X}$ en la casilla correspondiente.

1. ¿Considera usted de utilidad los cursos de Inglés especializado, donde tenga la oportunidad de leer textos propios de su campo de estudio?
$\square$ sí
no
$\square$ ¿Por qué? 
2. ¿Con qué frecuencia utiliza usted materiales de lectura en inglés en sus cursos o en su vida profesional?

$\square$ siempre $\square$ con frecuencia $\square$ a veces $\square$ nunca

3. ¿Qué tipo de análisis de lectura (resúmenes, cuestionarios, lectura crítica, resolución de casos, etc.) realiza en sus cursos?

4. ¿Cuáles son algunas de las dificultades que enfrenta a la hora de leer dichos textos?

$\square$ estructura gramatical

$\checkmark$ vocabulario

¿ comprensión de ideas generales

¿- comprensión de detalles

5. ¿Cuáles temas considera usted que deberían incluirse en el material de lectura para el curso de Inglés especializado?

6. ¿Qué tipo de textos utiliza usted principalmente en su campo de estudio correspondiente?

- noticias

$\succeq$ bibliografías anotadas

capítulos de libros $\quad \sqsubset$ artículos de Internet

… artículos de revistas $\quad$ otros 
7. ¿Cuáles fuentes utiliza usted con más frecuencia en su carrera?

$\square$ Internet

$\square$ Revistas

Libros

Periódicos

Ordenamiento jurídico (leyes, tratados internacionales, etc.)

$\square$ Otros(Especifique)

COMENTARIOS Y RECOMENDACIONES:

¡Muchas gracias por su colaboración! 


\section{Appendix 2}

The following text was used to exemplify several of the strategies discussed $^{21}$.

Featured Columnist:

What's In a Name? The Origins of Popular Place and Street Names around San José

Around Costa Rica

by Mitzi Stark

Paseo de los Estudiantes. Cuesta de Moras. Paseo Colón. Paso de la Vaca. All are place names that stand out among the numbered streets and avenues of San José. How did they get their names? And what has Paso de la Vaca (Cow Crossing) to do with cows? Or Cuesta de Moras (Blackberry Hill) with blackberries?

Numbered streets may seem unoriginal, but at least you know where you are when you arrive at Calle 6, Avenida 2. The number system came into being in San José in 1905 to eliminate confusion, and was adopted by other cities as well, though the preferred way to describe a location is still " 100 meters east and 25 meters south" of some wellknown landmark.

Before 1850, the avenues of midtown San José had names such as La Libertad (Liberty), Los Hermanos (The Brothers), La Gobernadora (The Governor) and Artillería Sabana (Sabana Artillery), which ran west to La Sabana where the army drilled.

Other streets bore names such as President, Independence, Concord, Peace and Alameda, which is now Avenida 10. Later, new names were affixed according to what lay along the route. Streets were named Calle de la Fábrica (Factory Street), de la Universidad (University), del Seminario (Seminary), de Chapuí (Asylum) and de Catedral (Cathedral) in the downtown area.

T Mitzi Stark. "What's In a Name? The Origins of Popular Place and Street Names around San Jose." The Tico Times. (August 26, 2005): 56. 
The 1890s was an era of prosperity, thanks to coffee exports and general economic improvement in Latin America. It was also a decade of French influence in the establishment of parks, plazas, fountains and statues. One result was a government decision to make all streets 20 meters wide, allowing for generous sidewalks, Parisian style, without realizing that every building in the city would have to be torn down to widen the streets. The law was rescinded in 1895, and street width was set at 14 meters, which may explain why the sidewalks are so narrow today.

Here's an explanation of several popular street names in San José : Paseo de las Damas. Avenida 3, in front of the National Library and the Atlantic Station. In 1890, the railroad to the Caribbean port city of Limón was completed, and this marked an important stage in the country's development, especially in commerce and communications. This being the "glorious era" and still under French influence, the new station called for a walkway lined with trees between the station and the downtown area, which became known as Paseo de las Damas. Although the name suggests a parade of strolling ladies in long silk skirts (one definition of damas is "ladies"), the damas were juniper berry trees (Citharexylum caudatum) that grew to great heights, produced beautiful fragrant flowers and housed bats that left stains on everything until public clamor resulted in the trees' removal.

Paseo de los Estudiantes. Calle 9, originally known as the Carretera a Desamparados (Highway to Desamparados). The little plaza in front of La Soledad Church was once the neighborhood market where farmers from Desamparados, south of San José, sold their products. Around 1900, this market moved to Avenida 14, Calles 9/11, where it remains today, though farmers now come in trucks rather than oxcarts. The plazabecame a green area where students (in Spanish, estudiantes) from the Liceo de Costa Rica and the Colegio Superior de Señoritas met. During the Federico Tinoco dictatorship (1917-19), the area was the scene of student protests against the government. Today, afterschool hours find the sidewalks of Paseo de los Estudiantes filled with students in gray uniforms from the nearby Liceo de Costa Rica. 
Desamparados. The name means "the abandoned"; why should this lively canton so close to San José have such a forlorn name? Back in the early 1800 s, the then-tiny village was called Dos Cercas (Two Fences), after the way it was described in the first deeds for the area. According to these documents, in 1817, Manuel Antonio Aguilar sold to José Ana Jiménez "a pasture in Two Fences along the road to Aserrí." Some historians even point to this area as the location of the lost city of Garcimuñoz, founded by the Conquistadors in 1561 .

The village of Dos Cercas, like all Costa Rican villages, had a church and patron saint; the saint chosen by this town's parish was La Virgen de Los Desamparados (the Virgin of the Abandoned). A statue of the virgin was brought from Guatemala in the early 1800 s, and is presently housed in the Joaquín García Monge museum in Desamparados.

Paseo Colón. Like the country's currency, this major boulevard was named for Christopher Columbus, the first European tourist to these shores (Colón is the Spanish form of Columbus). The thoroughfare was dedicated to the famous explorer in 1932, partly because someone erroneously measured the length of the street at 1,492 meters, and thought it was fitting. The street existed long before that time as a dirt road connecting San José to the westem suburb of Escazú and the town of Santa Ana, southwest of the capital.

In the 1700s, smoking had become a fad in the old country, and tobacco was a big crop in the Central Valley, generating a movement of people into the area. In 1793-94, Manuel de la Torre y Romero laid out the city of San José in squares, but only up to Calle 10. West of that was a common area for pastures and La Sabana Park. Around the 1850s, after the establishment of the hospitals, this part of Avenida Central became popular for commercial and government buildings, and the tranvía (electric trolley) ran along this avenue. In 1932, the name was changed to Paseo Colón.

Hatillo or Los Hatillos. This name, according to legend-or gossipcomes from the word hato, which means "a head of 100 cattle." Purportedly, one farmer kept his hato corralled in the area, followed by other farmers with their hatos, and the area became known as Hatillos. 
Cuesta de Moras. The famous "hill of blackberries" around Avenida Central and Calles 15/17 has nothing to do with the juicy fruit, as the name might imply, but rather to the Mora family. The distinguished Moras trace their Costa Rican ancestors to Juan de Mora Salado, who died here in 1621. Among his descendants are former Presidents Juan Mora Fernández, the country's first head of state, and Juan Rafael Mora Porras, who organized Costa Rican forces against U.S. filibuster William Walker in the Campaign of 1856.

In the early 1700s, thanks to the generosity of the Spanish crown, Juan and Basilio Mora owned large farms along the road from the former capital, Cartago, east of San José, to what was then the village of Boca del Monte (San José), where they kept cattle and grew wheat. As long ago as 1763 , the name Cuesta de Moras was used in documents to identify the area.

Paso de la Vaca. This refers not to the market known by this name but to Calle 8, near the Torres River, which was once the river crossing for the route to Heredia, north of San José. Back in early times, it was the custom for people to erect life-size Nativities for the Christmas season, which lasted until Candlemas Day, Feb. 2. It was also customary to have a real donkey and ox in the Nativity scene to keep the Christ child warm. Around 1840, the family occupying the land along this route had no donkey or ox, so they put their cows (vacas, in Spanish) in the Holy Family's abode, and all those passing along this highly transited road began calling it Paso de la Vaca. The name still sticks.

Old photos of some of the above can be seen at www.acharita.com. Information for this article is courtesy of the Ministry of Culture, Youth and Sports, the National Library, historian Guillermo Villegas and taxi driver Rodolfo. 